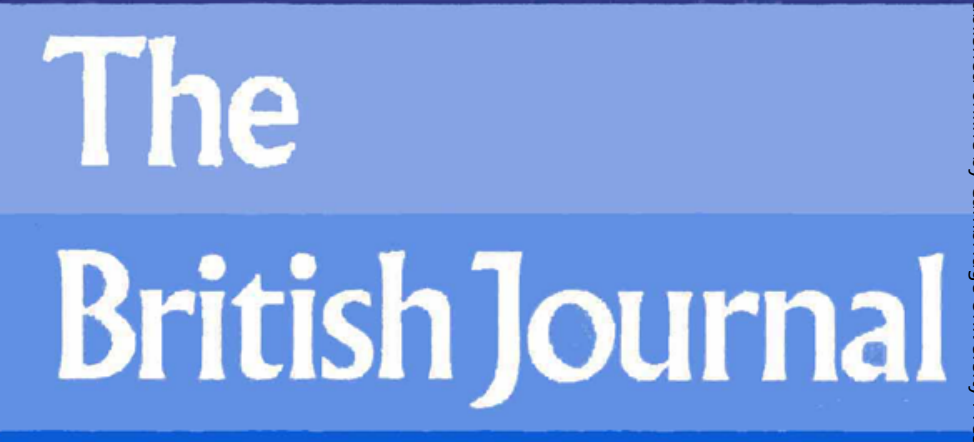

\title{
of Nutrition
}

VOLUME 64 NUMBER I JULY 1990 


\section{Edited for the Nutrition Society}

EDITORIAL BOARD

J. R. Arthur
C. J. Bates
D. O. Chanter
T. J. Cole
J. H. Cummings
M. S. Dhanoa
S. J. Fairweather-Tait
M. Gill

R. F. Grimble

P. H. Holmes

A. A. Jackson

M. J. Jackson

I. T. Johnson

P. Kelly

G. E. Lobley

M. A. Lomax
K. J. McCracken

J. C. MacRae

J. A. Milne

S. V. Morant

M. Nelson

I. M. Nevison

G. A. J. Pitt
A. Prentice

T. A. B. Sanders

J. D. Sutton

M. G. Tuck

K. W. J. Wahle

C. C. Whitehead

A. F. Williams

D. A. T. Southgate (Chairman)

EDITORIAL ADVISERS

$\begin{array}{llll}\text { P. J. Aggett } & \text { M. B. Duggan } & \text { R. E. Hughes } & \text { J. A. Rooke } \\ \text { J. M. Bassett } & \text { G. G. Duthie } & \text { F. J. Kelly } & \text { I. R. Rowland } \\ \text { I. Bremner } & \text { G. C. Emmans } & \text { T. J. A. Key } & \text { M. Salter } \\ \text { R. Bruckdorfer } & \text { M. Enser } & \text { A. B. McAllan } & \text { C. J. Schorah } \\ \text { R. A. Clegg } & \text { A. Faulkner } & \text { G. McNeill } & \text { H. S. A. Sherratt } \\ \text { W. H. Close } & \text { D. J. Flint } & \text { A. MacPherson } & \text { E. R. Skinner } \\ \text { M. E. Coates } & \text { A. Flynn } & \text { D. J. Millward } & \text { J. F. Soothill } \\ \text { B. Crabtree } & \text { J. M. Forbes } & \text { D. S. Parker } & \text { S. Southon } \\ \text { D. C. Davidson } & \text { M. J. Gibney } & \text { J. Pearce } & \text { M. J. Stock } \\ \text { D. I. Demeyer } & \text { F. W. Heaton } & \text { J. M. Pell } & \text { L. Stockley } \\ \text { P. F. Dodds } & \text { R. Hill } & \text { J. Price } & \text { N. F. Suttle }\end{array}$

M. K. Theodorou

D. I. Thurnham

L. F. Villard-

Mackintosh

P. A. Wharton

A. P. Williams

C. M. Williams

P. E. V. Williams

D. H. Williamson

The Nutrition Society has as its object the advancement of the scientific study of nutrition and its application to the maintenance of human and animal health.

Application for membership is invited from anyone whose work has contributed to the scientific knowledge of nutrition, whether such work has been in the laboratory, the field or the clinic, and whether experimental, clinical, agricultural or statistical in nature. There is also a student membership scheme with reduced subscriptions.

Particulars of the Nutrition Society and application forms for membership may be had from the Honorary Secretary, Dr R. F. Grimble, The Nutrition Society, Grosvenor Gardens House, 35-37 Grosvenor Gardens, London SW1W 0BS.

The British Journal of Nutrition (ISSN 0007-1145) is published once every two months by Cambridge University Press for The Nutrition Society, which owns it and controls its publication. A volume consists of three parts and two volumes appear each year. For 1990, the annual Nutrition Research Reviews is included as a supplement.

Subscriptions to the Society's Publications. For non-members of The Nutrition Society the subscription including postage, to volumes 63 and 64,1990 of the Journal, is $£ 180.00$ in UK, $£ 187$ elsewhere, payable in advance to Cambridge University Press, The Edinburgh Building, Shaftesbury Road, Cambridge CB2 2RU, or to any agent. The subscription in USA and Canada is US $\$ 390.00$, and inquiries there should be addressed to Cambridge University Press, Journals Department, 40 West 20th Street, New York, NY 10011. Single issues are $£ 30.00$ (US \$69.00 in USA and Canada); single copies of Nutrition Research Reviews are $£ 39$ (US \$79); postage extra. All orders must be accompanied by payment. POSTMASTER: send address changes in USA and Canada to British Journal of Nutrition, Cambridge University Press, 110 Midland Avenue, Port Chester, New York, NY 10573.

A claim for the replacement of a publication lost in transmission will not be entertained unless made immediately on receipt of the subsequent issue.

Second class postage paid at New York, NY and at additional mailing offices.

For details of the Proceedings of the Nutrition Society, and copying, see inside back cover. 